\title{
INVESTIGATION OF THE SOLUBILITIES OF SULFATED AND GROUND PHOSPHATE ROCK AFTER SULFATION IN $\mathrm{H}_{2} \mathrm{SO}_{4}$ SOLUTION
}

\section{SÜLFATLANAN VE SÜLFATLANMA SONRASI ÖĞÜTÜLEN FOSFAT KAYASININ $\mathrm{H}_{2} \mathrm{SO}_{4}$ ÇÖZELTISSINDE ÇÖZÜNÜRLÜKLERİNİN İNCELENMESİ}

\author{
Melike SINIRKAYA ${ }^{1 *}$, A. Kadir ÖZER ${ }^{1}$, M. Şahin GÜLABOĞLU ${ }^{1}$ \\ ${ }^{1}$ Department of Chemical Engineering, Atatürk University, Erzurum, Turkey. \\ melikesinirkaya@gmail.com, kadirozer@atauni.edu.tr, msahin@atatuni.edu.tr
}

\section{Abstract}

In this study, the effects of temperature and acid concentration on the dissolution of the sulfated and ground after sulfation phosphate samples in sulfuric acid solution obtained after flue gas desulfurization were investigated and the results were compared for both samples. It was observed that the dissolution rate increased as the temperature and acid concentration increased during the dissolution of sulfated and ground after sulfation phosphate samples. It was shown that the dissolution reaction can be divided into two regions, with different rate controlling steps for both samples. The controlling step was determined as pseudo-first order reaction at low conversions and diffusion through the product (ash) layer at high conversions.

Keywords: Flue gas desulfurization, Sulfated phosphate rock, Dissolution kinetics

\section{Introduction}

Phosphoric acid is a major component of many fertilizers. It is mainly produced by digestion of phosphate rock with sulfuric acid. This yields phosphoric acid as a product and hydrated calcium sulfate as a byproduct [1]. The carbonates in phosphate rocks consume additional $\mathrm{H}_{2} \mathrm{SO}_{4}$ during the production of phosphoric acid and super phosphates. During the reaction, the produced carbon dioxide causes more foaming and produces smaller sized gypsum crystals, which may blind the filters and, as a result, a low-quality phosphoric acid may be produced [2].

On the other hand, emissions of $\mathrm{SO}_{2}$ from different industrial activities, such as power production, the metallurgical industry and cement production, are undesired due to its harmful effects. High sulfur-containing coal can be burned while maintaining low $\mathrm{SO}_{2}$ emissions without substantial decrease in combustion efficiency by using a suitable sorbent as the bed material. The most commonly used sorbents in these procedures are calcium-based materials; in particular, limestone and dolomite, which capture released sulfur oxides in the form of calcium sulfate [3].

The major disadvantage of using a natural limestone or dolomite as a bed material is related to environmental factors, which include the carrying of large quantities of limestone particles. There is limited utility for the solid waste obtained from flue gas desulfurization of basic materials such as limestone and dolomite. If this byproduct (calcium sulfate) is used in the industry, the environmental problem will be reduced [4]. and this method will be useful from the economical point of view.
Öz

Bu çalıșmada, baca gazı desülfürizasyonundan elde edilen sülfatlanmıs ve sülfatlanma sonrası öğütülen fosfat örneklerinin H2SO4 çözeltisinde çözünürlükleri üzerine sıcaklık ve asit konsantrasyonunun etkileri incelendi ve her iki örnek için elde edilen sonuçlar karş̧laştırıldı. Sülfatlanan ve sülfatlanma sonrası ögütülen fosfat örneklerinin çözünmesi esnasında sıcaklık ve asit konsantrasyonu arttıkça çözünme hızının arttığı gözlendi. Çözünme reaksiyonunun her iki örnek için farklı hız kontrol basamaklarına sahip iki bölgeye ayrılabileceği görüldü. Kontrol basamağının düşük dönüşümlerde yalancı birinci mertebe reaksiyon, yüksek dönüşümlerde ürün (kül) filminden difüzyon kontrollü olduğu belirlendi.

Anahtar kelimeler: Baca gazı desülfürizasyonu, Sülfatlanmıș fosfat cevheri, Cözünme kinetiği

In our previous works by our research group, physical structure, chemical and mineralogical composition of the phosphate rock has been investigated [5]. The results of X-ray powder diffraction analysis showed that the main minerals of the rock are calcite, fluorapatite, and carbonate-fluorapatite. It was found that the rock consists of two different phases, namely, calcite-rich phase and phosphorus-rich phase, which were dispersed heterogeneously.

In another study, the authors investigated the possibility of using the Mazıdağı phosphate rock as an alternative to basic materials such as limestone and dolomite in the flue gas desulphurization. The results showed that the conversion of sulphate obtained in the case of phosphate rock is higher than that obtained with limestone and dolomite [6].

Several studies have been carried out on the dissolution of phosphate rock. The performances of partially acidulated phosphate rocks prepared from different acid mixtures were investigated. It was found that among the acid mixtures as acidulants, $\mathrm{HNO}_{3}+\mathrm{H}_{3} \mathrm{PO}_{4}$ were the best [7]. Also, the kinetics of dissolution of the phosphorite in $\mathrm{HCl}$ was previously investigated. The study showed that the decomposition of phosphorite rock by hydrochloric acid was enhanced by partially replacing the acid with sulfuric acid [8],[9].

In our another study, the dissolution kinetics of the raw and the sulfated samples were examined and it was obtained that the product obtained at the end of desulfurization needs less sulfuric acid for dissolution, thereby the sulfated phosphate rock would be better material than raw phosphate rock for phosphoric acid production [10]. In the light of these observations, this study intended to investigate the effects of the temperature and acid concentration on the dissolution of 
both sulfated and the phosphate rocks ground after having been sulfated in sulfuric acid solution. The dissolution kinetics was also investigated.

\section{Experimental}

\subsection{Material and Methods}

Phosphate rock used in this investigation was obtained from phosphate deposits in the Mazıdağı/Mardin/Turkey. The sample was crushed, ground and sieved. The sulfation experiments were carried out with phosphate samples having particle sizes between 500-710 $\mu \mathrm{m}$ in a laboratory-scale fluidized bed. The chemical analysis of the phosphate rock was carried out by standard gravimetric, volumetric, and spectrometric methods, and the results of chemical analysis are given in Table 1 . The details of the apparatus used for the flue gas desulfurization with phosphate rock are given elsewhere [11]. In order to remove the oxides formed by the decomposition of carbonate, a quenching process was applied to the sulfated sample by taking the sample into the water, mixing in a beaker manually, decanting the solution and finally filtering it. The washed sample was dried at $383 \mathrm{~K}$ and a part of it was ground. So the dissolution experiments were carried out on both samples; the sulfated phosphate sample and the one ground after sulfation.

Table 1: Chemical analysis of the phosphate rock sample.

\begin{tabular}{ll}
\hline \multicolumn{1}{c}{ Components } & \multicolumn{1}{c}{ wt (\%) } \\
\hline $\mathrm{CaO}$ & 50.27 \\
$\mathrm{P}_{2} \mathrm{O}_{5}$ & 23.27 \\
$\mathrm{MgO}$ & 1.60 \\
$\mathrm{Fe}_{2} \mathrm{O}_{3}$ & 0.03 \\
$\mathrm{Al}_{2} \mathrm{O}_{3}$ & 1.13 \\
$\mathrm{SiO}_{2}$ & 4.05 \\
$\mathrm{~F}_{2}$ & 3.60 \\
Loss on ignition $\left(\mathrm{CO}_{2}\right)$ & $14.85(11.23)$ \\
\hline
\end{tabular}

\subsection{Apparatus}

In a our previous study [11], the simultaneous calcination and sulfation of the phosphate rock in a differential fluidized bed reactor using a reaction gas similar to the flue gas composition $\left(0.3 \% \mathrm{SO}_{2}, 4 \% \mathrm{O}_{2}, 15 \% \mathrm{CO}_{2}\right.$ and the rest $\left.\mathrm{N}_{2}\right)$ were investigated. The effect of temperature on the $\mathrm{P}_{2} \mathrm{O}_{5}$ content of samples quenched after sulfation was investigated. The highest ratio of $\mathrm{P}_{2} \mathrm{O}_{5}$ was obtained during the 4 min sulfation period at $1123 \mathrm{~K}$. Regarding the results obtained previously, the samples having the highest phosphate conversion (34 wt\%) which were obtained after sulfation for $4 \mathrm{~min}$ at $1123 \mathrm{~K}$ were chosen for the current study [12].

The dissolution process was carried out in a $750-\mathrm{ml}$ jacketed cylinder glass reactor (inner diameter of $7 \mathrm{~cm}$ ) at atmospheric pressure. The reactor is monitored by a thermostat, which is equipped with a digital controlled mechanical stirrer and a thermometer, to keep the reactor contents at a constant temperature. In addition, a condenser was installed on the reactor to prevent losses by evaporation.

For each run, $500 \mathrm{ml}$ of sulfuric acid at a definite concentration was transferred into the reactor at the required temperature. The reaction was initiated by the addition of a known amount of sulfated phosphate sample, at time $t=0$, while stirring the content of the reactor at a known speed. A 3-ml sample was withdrawn from the reactor at predetermined time intervals and was filtered immediately. The phosphate content of the filtrate as $\mathrm{P}_{2} \mathrm{O}_{5}$ percent was determined by gravimetric analysis with ammonium phosphomolybdate [13]. Each experiment was repeated three times, and the arithmetic average of the result of the three experiments was used in the kinetic analysis. The procedure given above was applied to both sulfated and ground samples after sulfation.

\section{Results and Discussion}

\subsection{Effect of Reaction Temperature}

The effect of the reaction temperature ( $\mathrm{T}$ ) on the reaction rate was investigated at 298, 313, 328, 343 and $363 \mathrm{~K}$ with a stirring speed of $800 \mathrm{rpm}$ and acid concentration of $80 \%$ (by weight). The results of the sulfated and ground after sulfation phosphate samples are shown in Figure 1. Since the sulfation process caused sintering and decreased in reacting area of the rock, the same experiments were made again by the ground samples obtained after sulfation. As can be seen from Figure 1, the dissolution rate increased as the temperature increased. The dissolution of ground samples after sulfation was increased at high temperatures, especially at initial rates of reaction and in short times. The phosphate conversion of sulfated samples was obtained as $26.2 \mathrm{wt} \%$ for $1 \mathrm{~min}$ at $363 \mathrm{~K}$, while the phosphate conversion of the ground samples after sulfation was $39.9 \mathrm{wt} \%$ at the same temperature and time. This result can be attributed to increased diffusion rate of ground samples after sulfation. But, in low temperatures, there weren't significant increases in the dissolution of the ground samples after sulfation. The phosphate conversion of sulfated samples was obtained as $31 \mathrm{wt} \%$ for $90 \mathrm{~min}$ at $298 \mathrm{~K}$, while the phosphate conversion in the ground samples after sulfation was $35.6 \mathrm{wt} \%$ at the same temperature and time. It was seen in the results that the dissolution of the ground samples increased a little more than that of the ones that were not ground.

\subsection{Effect of Acid Concentration}

To observe the effect of $\mathrm{H}_{2} \mathrm{SO}_{4}$ concentration on the dissolution, experiments were carried out using the concentrations of $20,40,60,80$ and $98 \%$ (by weight) at a reaction temperature of $343 \mathrm{~K}$ with a stirring speed of 800 $\mathrm{rpm}$. As depicted in Figure 2, the dissolution rate increased as the acid concentration and time increased in the range of values studied. It was also determined that the phosphate conversion increased with decreasing particle size after grinding. This can be attributed to the increase in surface area with the decrease in grain size which leads acid to reach the phosphate parts in the rock easily.

\subsection{Reaction Kinetics}

In kinetic studies, models are often used for evaluation of kinetics parameters, as well as for process simulations. The proper choice of model is therefore critical for both the extraction of the right kinetic parameters from experimental data and optimal process simulations. The rate of a noncatalytic reaction between a solid and a fluid can be expressed by one of unreacted-core model and progressive conversion model [14]. The kinetic data of the present study were analyzed through the graphical and statistical methods applied in the calculation. When the experimental data obtained were analyzed using fluid-solid heterogeneous reaction models by graphical and statistical methods, straight lines passing through the origin were not obtained, and low regression coefficients were found, but there were fairly good correlations when they were separately applied to the data 
before and after the inflection points of the curves Figures 1 and 2.

The particular model is assumed to be adequate when experimental points may be arranged on a straight line. Experiments were conducted at 298, 313, 328, 343 and $363 \mathrm{~K}$ to calculate the apparent activation energy of the reaction.

Therefore, the agreement of the experimental data with the Avrami kinetic model for different temperatures was investigated. The dissolution process was found to follow the Avrami model [15]. In accordance with these results, the equation representing the kinetics of this process can be expressed as given in Eq (1).

$$
-\ln (1-\mathrm{X})=\mathrm{k}_{0} \mathrm{Ca}^{\mathrm{a}} \mathrm{e}^{-\mathrm{E} / \mathrm{RT} \mathrm{t}}
$$

Where $\mathrm{C}$ is the initial acid concentration $\left(\mathrm{mol} \cdot \mathrm{dm}^{-3}\right), \mathrm{t}$ is the reaction time( $\mathrm{min}$ ) and $\mathrm{T}$ is the reaction temperature $(\mathrm{K})$.

On the other hand, as can be seen from Figure 1 and 2, the experimental points after the inflection for the sulfated and ground phosphate samples after sulfation were well correlated by Eq. 2, indicating the ash diffusion control. The function of this model can be written in the following model.

$$
1-3(1-\mathrm{X})^{2 / 3}+2(1-\mathrm{X})=\mathrm{k}_{0} \mathrm{Ca}^{\mathrm{a}} \mathrm{e}^{-\mathrm{E} / \mathrm{RT}} \mathrm{t}
$$

As can be seen in Table 2, the apparent activation energies at the pseudo- first order reaction of the sulfated and ground phosphate samples after sulfation were found to be 26.4 and $38.99 \mathrm{~kJ} . \mathrm{mol}^{-1}$, respectively. As for, the apparent activation energies at the diffusion through a product layer model for the sulfated and ground phosphate samples after sulfation were found to be 40.15 and $38.8 \mathrm{~kJ} . \mathrm{mol}^{-1}$, respectively.

The activation energy of the ground phosphate samples after sulfation was higher than that of the sulfated phosphate samples before the inflection points. There was no significant difference in the activation energies of the both samples after inflection points.

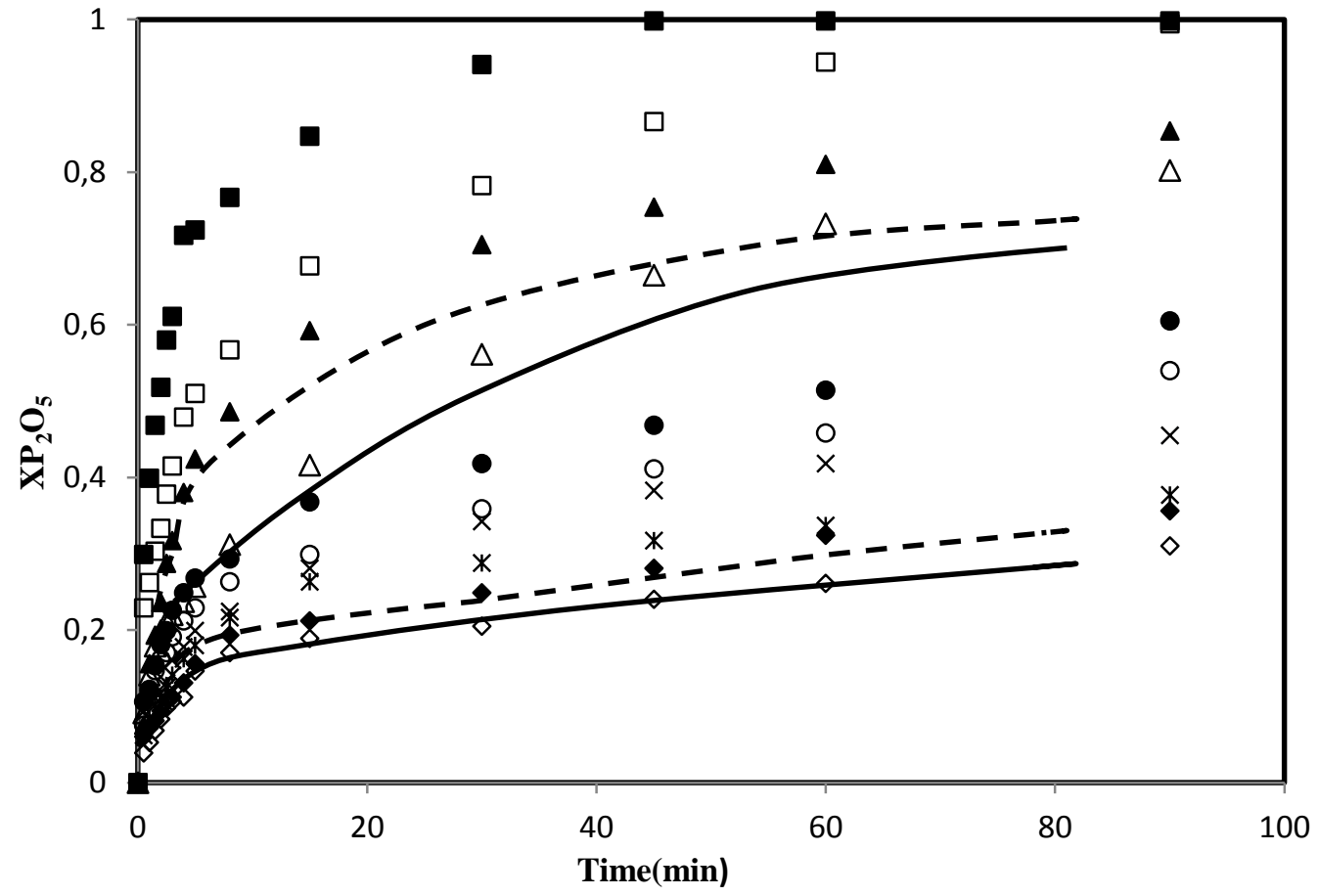

Figure 1. Effect of temperature on the dissolution of the sulfated phosphate sample and the phosphate sample ground after sulfation (acid concentration: $80 \% \mathrm{wt}$ ), temperatures $298 \mathrm{~K}(\diamond), 313 \mathrm{~K}\left({ }^{*}\right), 328 \mathrm{~K}(0), 343 \mathrm{~K}(\Delta), 363 \mathrm{~K}(\square)$ for sulfated phosphate sample, and 298 $\mathrm{K}(\bullet), 313 \mathrm{~K},(\times), 328 \mathrm{~K}(\bullet), 343 \mathrm{~K}(\boldsymbol{\Delta}), 363 \mathrm{~K}(\boldsymbol{\bullet})$ for the phosphate sample ground after sulfation

\begin{tabular}{|c|c|c|c|c|c|c|}
\hline \multirow[t]{2}{*}{ Models } & \multirow[t]{2}{*}{ Sample } & \multicolumn{5}{|c|}{ Kinetic parameters } \\
\hline & & $\mathrm{k}_{\mathrm{o}}$ & $\mathrm{E}\left(\mathrm{kj} \cdot \mathrm{mol}^{-1}\right)$ & $\mathrm{a}$ & $\mathrm{m}$ & $\mathrm{R}^{2}$ \\
\hline Pseudo-first order reaction model & sulfated sample & 0.65 & 26.4 & 3.1 & 0.5 & 0.95 \\
\hline & ground sample after sulfation & 1.11 & 39.0 & 4.7 & 0.62 & 0.97 \\
\hline Diffusion through a product layer & sulfated sample & 5842 & 40.2 & & & 0.97 \\
\hline & ground sample after sulfation & 4285 & 38.8 & & & 0.92 \\
\hline
\end{tabular}

Table 2: The values of predicted kinetics parameters. 


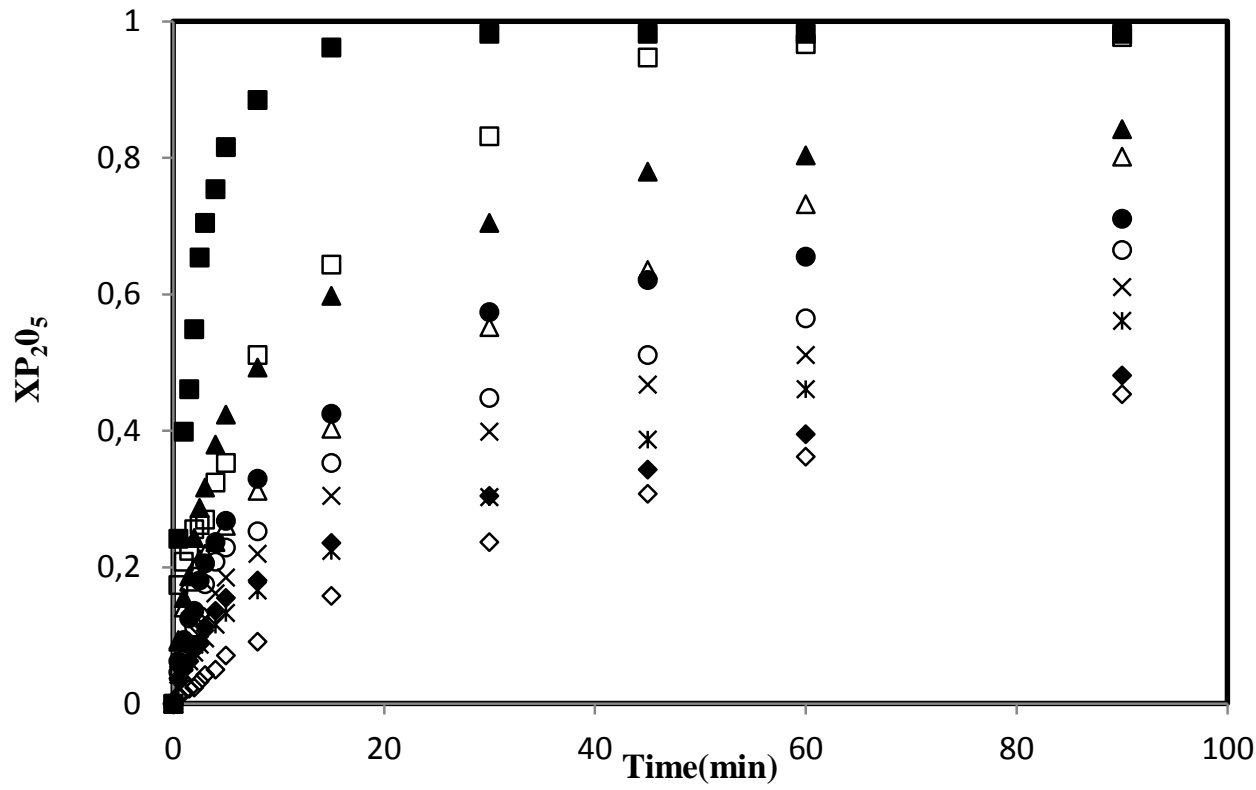

Figure 2. Effect of acid concentration on the dissolution of the sulfated phosphate sample and the phosphate sample ground after sulfation (temperature: $343 \mathrm{~K}$ ), acid concentrations $20(\diamond), 40\left(^{*}\right), 60(0), 80(\Delta), 98 \%(\square)$ for sulfated phosphate sample, and

$20(\bullet), 40(\times), 60(\bullet), 80(\Delta), 98 \%(\bullet)$ for the phosphate sample ground after sulfation (temperature: $343 \mathrm{~K})$

\section{Conclusions}

In this study, the effects of temperature and acid concentration on the dissolution of the sulfated and ground after sulfation phosphate samples in sulfuric acid solution obtained after flue gas desulfurization were investigated and the results were compared for both samples. The dissolution rate increased as the acid concentration and temperature increased during the dissolution process of both samples. Most of the resolution happens in the phosphate parts of the samples because some of $\mathrm{CaCO}_{3}$ transformed into $\mathrm{CaSO}_{4}$ during sulfation and some of the $\mathrm{CaO}$ forming during calcination removed as $\mathrm{Ca}(\mathrm{OH})_{2}$. This condition does not prevent the progress of the reaction. In low temperatures and concentrations, there weren't significant increases in the dissolution of the ground phosphate samples after sulfated.

The dissolution of ground samples after sulfation was increased at high temperatures and concentrations, especially at initial rates of reaction and in short times. This can be attributed to the increase in surface area with the decrease in grain size which leads acid to reach the phosphate parts in the rock easily.

It was seen in the results that the dissolution of the ground samples increased a little more than that of the ones that were not ground. It was observed that the dissolution reaction can be divided into two parts with different rate-controlling steps. The apparent activation energies for the sulfated phosphate rocks and the rocks ground after having been sulfated before inflection points were found to be 26.4 and $38.99 \mathrm{~kJ} . \mathrm{mol}^{-1}$. But the apparent activation energies for the sulfated phosphate rocks and the sulfated and then ground phosphate rock after inflection points were calculated as 40.15 and $38.8 \mathrm{~kJ}$. mol-1 respectively.

On the other hand, in technological applications, the raw phosphate rock is ground into the very small grain dimensions before being treated with acid in order to get grain liberalization. This causes the grinding process which is one of the most costly applications in industry. In the present work, the results show that grinding process is unnecessary to obtain more $\mathrm{H}_{3} \mathrm{PO}_{4}$. Since meeting the grinding expenses will not provide much benefit, utilization of the sulfated phosphate rock obtained after flue gas desulfurization in phosphoric acid production will reduce sulfuric acid consumption and economics will favor this process.

\section{References}

[1] Becker P. Phosphate and Phosphoric Acid. 2nd ed. New York, USA, Marcel Dekker Inc, 1983.

[2] Lodha TR, Sinha NK, Srivastava AC. "Characterization of Low Grade Rock Phosphate and Their Beneficiation for the Fertilizer". Chemical Age of India, 35(1), 15-22, 1984.

[3] Haji-Sulaiman MZ, Scaroni AW. "The Rate Limiting Step in the Sulfation of Natural Limestones During Fluidized Bed Coal Combustion". Fuel Processing Technology, 31(3), 193-208, 1992.

[4] Dennis JS, Hayhurst AN. "Alternative Sorbents for FlueGas Desulphurization, Especially in Fluidized-Bed Combustors". Journal of the Institute of Energy, 62, 202-207, 1989.

[5] Özer AK, Gülaboğlu M, Bayrakçeken S. "Physical Structure and Chemical and Mineralogical Composition of the Mazidagl (Turkey) Phosphate Rock". Industrial \& Engineering Chemistry Research, 39(3), 679-683, 2000.

[6] Özer AK, Gülaboglu M, Bayrakceken S, Weisweiler W. "Flue Gas Desulfurization With Phosphate Rock in a Fluidized Bed". Fuel, 81(1), 41-49, 2002.

[7] Basak RK, De GK. "Release of Phosphorus From Partially Acidulated Rock Phosphate in a Typic Ustifluvent". Journal of the Indian Society of Soil Science, 45(6), 759-762, 1997. 
[8] Olenipekun EO, Bamgbose JT. "Reaction Kinetics for the Leaching of Impurities From Rock Phosphate". Pakistan Journal of Scientific and Industrial Research, 41(3), 116120, 1998.

[9] Olenipekun E0. "Kinetics of Dissolution of Phosphorite in Acid Mixtures". Bulletin of the Chemical Society of Ethiopia, 13(1), 63-70, 1999.

[10] Sınırkaya M, Özer AK, Gulaboglu MŞ. "Kinetics of Dissolution in $\mathrm{H}_{2} \mathrm{SO}_{4}$ of Sulfated Phosphate Rock". Minerals Metallurgical Processing, 29(3), 156-158, 2012.

[11] Sınırkaya M, Bayrakçeken H, Özer AK, Gülaboğlu MŞ. "The Effect of Carbon Dioxide during the Desulfurization of Flue Gas With Mardin-Mazıdagı Phosphate Rock". Fuel, 87(15-16), 3200-3206, 2008.
[12] Sınırkaya M, Özer AK, Gülaboğlu MŞ. "Investigation of the Changes of $\mathrm{P}_{2} \mathrm{O}_{5}$ Content of Phosphate Rock during Simultaneous Calcination/Sulfation". Powder Technology, 211(1), 72-76, 2011.

[13] Furman NH. Standart Methods of Chemical Analysis, 6th ed. New Jersey, USA, D. Von Nostrand Company, 1963.

[14] Levenspiel 0. Chemical Reaction Engineering. 3rd ed. New York, USA, John Wiley and Sons, 1999.

[15] Avrami M. "Granulation, Phase Change, and Microstructure Kinetics of Phase Change. III". The Journal of Chemical Physics, 9(2), 177-183, 1941. 